\title{
Narrativas de viagem de Nísia Floresta
}

Constância Lima Duarte*

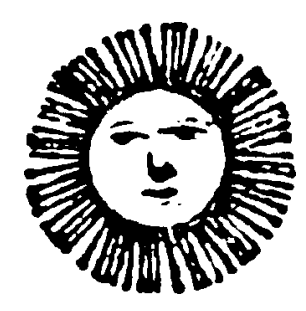

* Universidade Federal de M inas Gerais e Universidade Federal do Rio Grande do Norte. 
É triste ver-se, querer-se bem, para deixar-se logo em seguida! São assim, no entanto, as ligações de turistas! M eu espírito ama as viagens, meu ser físico nelas se compraz, mas meu coração nunca será viajor.

Nísia F loresta

Sou sujeito a estas distrações, a este sonhar acordado: Que hei-de eu fazer? Andando, falando, escrevendo, sonho e ando, sonho e falo, sonho e escrevo.

Almeida Garrett

Nesse final de milênio pós-moderno, quando mais se destacam os estudos culturais e a neo-história, mais oportuna se torna a leitura de certos livros que uma mulher de estranho nome - Nísia Floresta B rasileira Augusta - um dia publicou em terras estrangeiras. E sta autora vai se impor, dentre as demais brasileiras letradas do século XIX, não só pela extensa produção intelectual - quinze títulos, dos mais variados gêneros - como por ter se insurgido pioneiramente contra os preconceitos sociais de seu tempo.

Nascida no interior do R io Grande do Norte, em 1810, com o nome de Dionísia Gonçalves Pinto, Nísia F loresta residiu em Pernambuco, R io Grande do Sul e R io de J aneiro, antes de se mudar para a Europa, em 1849, e residir ora em Portugal, 
I nglaterra, I tália ou F rança, e viajar incansavelmente pelos países do Velho M undo, até falecer, em 1885, em Rouen, interior da França.

Esta foi, com certeza, uma das primeiras mulheres no Brasil a romper os limites do espaço privado e a publicar textos na grande imprensa, pois, desde 1830, seu nome era uma presença constante em periódicos nacionais, comentando questões polêmicas, como o direito das mulheres - e, também, dos índios e dos escravos - a uma vida digna e respeitável. Aliás, nesse gosto pela polêmica e no fato de viver sempre à frente de seu tempo, estariam, a nosso ver, também, traços de modernidade da autora.

Entre os principais títulos de Nísia F loresta, lembramos o Di reitos das muIheres e injustiça dos homens (1832), inspirado em Vindications of the rights of woman, de Mary Wollstonecraft, que denuncia o preconceito contra a mulher na sociedade brasileira e tenta desmistificar a idéia dominante da superioridade masculina; o Consel hos à minha fi lha (1842), o Opúsculo humanitári o (1853) e A mulher (1859), que discutem questões relativas à educação e à condição feminina; e o poema A lágrima de um Caeté (1849), que, diferente da maioria dos textos indianistas, traz o ponto-de-vista do índio consciente de sua derrota histórica e inconformado com a opressão do invasor.

No mesmo ano da publicação desse livro, Nísia F loresta viajou para a E uropa, onde se relacionou com grandes escritores como Alexandre Herculano, Antônio Feliciano de Castilho, Alexandre Dumas, L amartine, Duvernoy, Victor Hugo, G eorge Sand, Manzoni, Azeglio e Auguste Comte, e viajou durante anos seguidos pela Itália, P ortugal, A lemanha, B élgica, G récia, F rança el nglaterra, até fixar-se em R ouen.

Em Portugal, residiu por diversas ocasiões em Lisboa, como no ano de 1851, e teve oportunidade de viajar pelo país e de fortalecer os laços de amizade com alguns de seus autores. No Instituto Histórico e Geográfico do Rio de J aneiro, aliás, está o exemplar de Opúsculo humanitário dedicado a Herculano e, em $\mathrm{O}$ Brasil Ilustrado, de 30 de abril de 1855, encontra-se o poema com que a autora homenageou Castilho, intitulado "Um improviso".

$\mathrm{O}$ registro das viagens de Nísia F loresta pela E uropa foi bem pouco conhecido do público nacional, principalmente por ter sido escrito em língua estrangeira e ter ficado muitas décadas esgotado. São eles: I ti nérai red'un voyageen Allemagne e Trois ans en Italie, suivis d'un voyage en Grèce. O primeiro foi publicado em Paris, em 1857, e traduzido para o português somente em 1982. O segundo, também publicado em Paris em dois alentados volumes, em 1864 e em 1872, apesar de considerad o por mais de um crítico uma obra-prima, onde a autora teria alcançado a culminância de seu esplendor intelectual, permanceu inédito em língua portuguesa até o presente ano, quando teve seu primeiro volume traduzido elançado em português. 
Nos dois livros, ela realiza o caminho inverso dos estrangeiros que aqui vinham "descobrir" o Brasil, isto é, percorre novas terras, estuda os costumes dos povos e visita os pontos mais pitorescos, agindo como a típica viajante ilustrada que sabe de antemão o que quer conhecer. Seus livros de viagem, escritos sob a forma de diário ou de cartas aos parentes distantes, pretendem revelar, bem ao gosto daquela época (e também da nossa), as emoções e impressões da autora diante de cada cidade ou país que visita, bem como as reflexões que faz perante as ruínas ou fatos históricos que presencia. Nísia F loresta realiza, portanto, muito mais que simples relatos, pois descreve com sensibilidade e erudição cada cidade, igreja, museu, parque, biblioteca e monumento, e os tipos humanos que encontra.

Quando a autora redige suas observações, ela está se inscrevendo, conscientemente, num dos gêneros literários mais em voga na E uropa daquela época, que era precisamente o das narrativas de viagem. $E$, dentre todos, os textos sobre viagens à I tália e à A lemanha se destacavam pelo numeroso repertório, chegando a consolidar uma "tradição" de se escrever sobre os dois países. A Alemanha, inclusive, parece ter sido o país mais visitado pela maioria dos ilustres viajantes do século XIX, seguido de perto pela I tália e Espanha. (DUARTE : 1995)

Tal modalidade literária - as narrativas de viagem - consistia, principalmente, no registro do escritor acerca de um lugar, privilegiando fatos ou instantâneos que melhor se amoldassem ao seu interesse narrativo. Na maioria das vezes, os textos resultam de laboriosa pesquisa e revelam a preocupação com o que já tinha sido dito e com o destinatário, mesmo quando existe a afirmação que não se pretendia publicá-los. A julgar pelas informações minuciosas e pela literariedade presente na maioria deles, é difícil acreditar nesta intenção e imaginar que tais relatos se destinavam a ficar confinados numa única gaveta ou circulando em poucas mãos.

Dentre as muitas reflexões que surgiram na E uropa, acerca do procedimento a ser adotado pelos viajantes, destacam-se as de J ean J . R osseau. Segundo o autor,

“O bserva-se toda a região; olha-se para a esquerda e para a direita; examina-se o que apraz e a gente se detém quando se agrada do lugar. (...) Não basta para se instruir percorrer os países; é preciso saber viajar. Para observar é preciso ter olhos e voltá-los para o objeto que se quer conhecer. (...) Há muita diferença entre viajar para ver terras e viajar para ver povos. O primeiro objeto é o dos curiosos, o outro é apenas acessório. Deve ser o contrário para quem quer filosofar. A criança observa as coisas à espera de que possa observar os homens. O homem deve começar por observar os homens; depois observará as coisas, se tiver tempo." (ROUSSEAU: 1968; 494, 544, 548)

A arte de viajar incluía ainda a realização de longos passeios a pé, observando o que se apresentasse no trajeto, como os minerais, os fósseis, as plantas, a 
natureza, a cultura e os costumes do país. Nísia F loresta, veremos, assimilou estas lições roussenianas e viajará também comme il faut.

Ora, enquanto no B rasil bem poucos se ocuparam com esta modalidade literária, no Velho Mundo foram muitos os autores e os títulos de narrativas de viagem que se tornaram conhecidos, como G oethe, autor de Italian journey (1786); ou Catteau-Calleville que publicou Voyage en Allemagne et en Suède (1810). M as, dentre todos, o livro de M me. de Stäel, De L'Allemagne, de 1810, destaca-se não só pela influência que exerceu sobre os românticos, como pela tumultuada história de sua publicação. Escrito a partir das viagens de 1803 e 1808, quando conhece Goethe, Schiller, Herder, K linger e Schlegel, o livro provocou o rompimento da autora com Napoleão, que o considerou não patriótico. Os conselhos para os franceses se mostrarem mais favoráveis às novidades do estrangeiro, principalmente a filosofia e literatura alemãs, tiveram a repercussão por demais conhecida. Quando, quarenta anos depois, Nísia F loresta realiza a sua viagem pela Alemanha, ela se refere algumas vezes à escritora, demonstrando o quanto a conhecia e admirava suas obras.

Em 1840, Victor Hugo visita a Alemanha e, em Voyages, revela a preferência por locais históricos e medievais e a emoção diante dos monumentos. Para ele, como também para Nísia Floresta, as ruínas, exercem um fascínio especial. Em Heidelberg, por exemplo, - no berço do movimento romântico - confessa ter ficado horas na contemplação de cada detalhe das suas famosas ruínas observandoas durante o dia e à luz da lua. E m Aix-La-Chapelle, Hugo rende homenagens a Carlos Magno, tal como faz nossa autora. Aliás, o Itinerário nisiano em alguns trechos, como aquele em que se encontra diante do túmulo de Carlos Magno, realiza interessante diálogo com o texto Voyages, acompanhando de perto as descrições que o escritor francês faz do túmulo real e da história dos despojos, despedaçados pela igreja para melhor explorá-los.

Outro viajante ilustre, Almeida Garrett, é sabido, preferiu excursionar pela própria terra, mas seu registro contém também alguns detalhes que podem ser considerados semelhantes ao que observamos no I tinerário de Nísia Floresta. A personalização de seres inanimados, a adjetivação excessiva, a presença de um interlocutor e o destaque do pitoresco são alguns desses pontos. G arrett conduz seu leitor de divagação em divagação como se conversasse com ele, comove-se diante de paisagens tipicamente românticas, quase como a escritora do Itinerário fez em seu texto. M as em outros aspectos os escritos se diferenciam. Por exemplo: Viagens na minha terra faz um mergulho na lusitanidade, recupera antigos costumes populares e conta uma história de amor, em meio à narrativa da viagem. J á o texto nisiano, ao se referir à própria terra, o faz dirigindo-se a um país que conserva apenas na memória, já idealizado pela lembrança. 
Vejamos mais detidamente cada um dos livros de viagem de Nísia F loresta, com destaque para os aspectos inovadores de sua narrativa. Com o título de I ti néraire d'un voyage en Allemagne, este livro foi publicado em Paris em 1857, e quem assina o prefácio é E ugénie Pelserf que nos revela, entre outras coisas, a intenção da autora em não publicar o texto. Estas "impressões de viagem", sob a forma de cartas, pretendiam apenas "dar expansão a suas emoções junto ao coração da família", o que explicaria a intimidade contida em suas páginas. À medida que a narrativa se desenvolve, percebemos que esta correspondência diária, quase um relatório do dia-a-dia, cumpre a função de preencher a solidão da viajante convertendo-se num quase diário, onde a autora além de registrar as impressões do que vê, deixa-se levar pelo devaneio, tornando-se cada vez mais intimista.

Um ano após sua publicação, o livro mereceu uma respeitosa crítica por parte de J oel Cherbuliez, na Revue Critique des Livres Nouveaux, que observa a existência das inúmeras referências de caráter pessoal ao longo do texto. Segundo o crítico, era preciso conhecer melhor a autora para decifrar algumas passagens e expressões, que, para ele, soavam muito misteriosas. (CHERBULIEZ: 1858; 23)

Iti nerári o de uma viagem à Alemanha trata, pois, da primeira excursão realizada por Nísia Floresta ao país de Goethe passando pela B élgica e interior da F rança, entre agosto e setembro de 1856. A o todo, são trinta e quatro cartas escritas diariamente (apenas 4 de setembro não tem a carta correspondente), dirigidas ao filho e aos irmãos que residiam no Brasil. A primeira é datada de Bruxelas, 26 de agosto, e, a última, é de 30 de setembro de 1856, e foi escrita em Estrasburgo. 0 trajeto escolhido, ela nos explica: preferiu entrar na A lemanha pela Bélgica e sair por Kehl, para ir de Estrasburgo a Montbélliard. Nelas, a narradora descreve os momentos mais marcantes de seu percurso, reiterando em quase todas as páginas as saudades que sentia, o quanto desejaria estar fazendo tal passeio com toda a família e não só em companhia de Lívia, a única filha presente.

$E$ as razões que a levaram a realizar tal viagem também são reveladas logo de início: a aproximação do primeiro aniversário de morte da mãe, o desejo de conhecer outros países e, também, de fazer uma peregrinação ao túmulo "do venerável amigo, o sábio e bom Duvernoy", falecido no ano anterior.

“E ra-me necessário percorrer novos países, neles haurir novas impressões, sob um horizonte mais amplo, em atmosfera mais livre e, conseqüentemente, mais consentâneas com minhas preferências." (FLORESTA: 1982; 9)

Interessante observar que a morte a impulsiona para as viagens, que, por sua vez, conduzem-na de volta à vida. Toda a narrativa conserva uma tensão entre morte e vida, bem perceptível no clima fúnebre que preside o Itinerário. “Viajar, 
repito-Ihes, é o meio mais seguro de aliviar o peso de uma grande dor que nos mina lentamente". (F L ORE STA : 1982, 67) Mas à medida que o roteiro avança, ela fica menos melancólica e se refere cada vez menos à mãe e aos familiares, pois, sem perceber, deixa-se envolver pela movimentação normal da viagem:

“Passando de paisagem em paisagem, de ruína em ruína e de cidade em cidade, nesta poética Alemanha, contemplando suas magnificências naturais e artísticas, o espírito arrebatado pelo requinte da arte e pelos encantos da natureza ora risonha e garrida, ora austera e recatada, minh'alma se prosterna, cada dia, perante o gênio benfazejo que me inspirou a idéia de visitar essas terras e me deu a coragem de executá-las." (FLORESTA: 1982; 89)

O país escolhido, sabemos agora, não poderia ter sido outro. Quem, naquela época, buscasse novas emoções, necessariamente ia ao berço do movimento romântico, à velha e poética Germânia, a pátria de Leibnitz e Kant, que preenchia com lirismo, tradição e exotismo, na dose certa, os espíritos românticos sedentos de aventura. A Alemanha era, não só para Nísia Floresta como para os demais escritores do tempo, o país da sensibilidade e da filosofia e, também, em suas palavras, "da poesia, do devaneio e amor, tanto quanto país de maravilhas do trabalho e do gênio humano."

A autora refaz o percurso de M me.de Stäel, Victor H ugo e outros viajantes e, como eles, também revela suas impressões. R ealiza assim o sonho de sua época ao conhecer a "terra-modelo", a terra de Werther, de Goethe; de Os salteadores, de Schiller; e, mais ainda, a terra do sturm und drang, cujo fascínio sobre a imaginação romântica ainda não havia se esgotado.

Nísia privilegia em seu relato não a história das cidades que visita ou a descrição de cada etapa do percurso, mas a própria subjetividade, pois transmite, principalmente, "uma imagem" de sua "alma", ou as "emoções" que os objetos e os lugares lhe despertam. Em dado momento, afirma:

“Não tenho tempo disponível para lhes escrever a história de Bruxelas (do que, aliás, vocês não precisam) nem das cidades que vou percorrer; indicarei apenas o que mais me atrai a atenção e, à noite, Ihes comunicarei minhas impressões do dia."(F LORESTA: 1982; 13)

A narradora se coloca de tal forma no centro da narrativa, que tudo o mais parece girar à sua volta. O que realmente importa para ela e, por conseqüência aos leitores, são as emoções e impressões que sente diante do que vê ou do que ouve. Ela não só seleciona o que vai contar, como explicita a maneira de fazê-lo: sua emoção diante dos acontecimentos funcionará quase como um filtro e só através dela conhecemos cada aspecto de sua viagem. Na descrição de um pas- 
seio, por exemplo, a narradora recorta a paisagem e enquadra apenas o que lhe interessa.

"E stes rochedos tocando as nuvens, estas montanhas, estes vales ataviados de verdura; estes bosques, ecoando o chilrear de mil pássaros diversos, que parecem festejar a presença do viajor em seu pacato deserto; o murmúrio docemente dolente de um modesto regato que timidamente vai misturar suas águas às do R eno soberbo; os passos rápidos da caça atemorizada que escapa; o silvo da brisa acariciando a folhagem e enviando-nos das circunvizinhanças o eco de mil contos fantásticos: tudo isto empresta um encanto indefinível à solidão destas paragens, e a alma fica em um êxtase, que a pena não pode exprimir." (FLO RESTA: 1982; 48-9)

Este, portanto, não será um simples roteiro de viagem. M uito mais que o trajeto percorrido entre uma cidade e outra, este itinerário conterá em suas páginas as diversas viagens que a narradora empreende ao mesmo tempo. A viagem propriamente dita que configura o presente da narrativa, é feita através das aldeias, cidades e vilas e nos é comunicada nas descrições que a narradora faz das paisagens, dos castelos ou igrejas que visita. M esmo as informações mais prosaicas - o meio de transporte utilizado, as distâncias percorridas, os preços dos bilhetes, a qualidade dos hotéis, os atropelos burocráticos das bagagens e das alfândegas - aí estão. Nestes momentos vem à tona o caráter de crônica própria ao gênero:

“Deixamos hoje Aix-la-Chapelle, pelas três horas da tarde, depois de haver visitado ainda algumas curiosidades. Chegando aqui, descemos no Hotel Clemente, cujo dono é casado com uma senhora agradável, que fala francês bastante bem. Tão logo ficamos instaladas em aprazível quarto no primeiro andar, de frente, dirigimo-nos a Deutz, aldeia do outro lado do R eno, que se comunica com Colônia através de uma ponte de barcos muito comprida." (FLORESTA: 1982; 35)

Mas o momento presente da viagem é apenas um ponto de partida e um estímulo para se alcançar o passado do lugar que visita. A visão de um monumento, de uma estátua ou de uma praça, por exemplo, tem o poder de provocar na viajante a lembrança de um vulto histórico ou de uma guerra acontecida séculos antes, no mesmo local. E é no momento da viagem pela história antiga da Alemanha que melhor pode se observar a erudição da cicerone, a pesquisa que realizou e o vasto conhecimento que possui da história. Em Coblença, por exemplo, quando se encontra diante de um castelo medieval, observa que

"Stolzenfel é um castelo que outrora servia de residência de verão aos eleitores de Treves; é célebre pela estada que ali teve o Arcebispo Werner, inteiramente entregue ao 
estudo da Alquimia. Este castelo, arrasado em 1688 pelos franceses, foi doado pela cidade de Coblença ao príncipe herdeiro da Prússia, que o mandou reconstruir ultimamente, com magnificência e no estilo da Idade Média. É um dos mais belos castelos do R eno. A Rainha Vitória nele permaneceu, alguns dias, com o marido. Os jardins que o cercam são magníficos." (FLORESTA: 1982; 52)

U ma terceira viagem realizar-se-á através de incursões na própria subjetividade, quando a narradora reflete a respeito do que está vivenciando ou dá vazão à nostalgia dos entes queridos. N esse momento, ela se auto contempla romanticamente e se faz espetáculo de si mesma e dos leitores. B usca conscientemente a solidão, os recantos mais escondidos dos bosques, dos campos, à margem dos rios e lagos, para melhor dar vazão à introspecção. É o momento intimista da meditação, em que o presente interior é revelado.

"Aqui, como aí, a imagem de vocês se reflete em meus olhos sobre os lençóis argênteos e riscados de ouro pelo sulco dos barcos que contemplo na vasta ponte enegrecida, em cujo centro se eleva a velha e austera estátua avermelhada de Carlos M agno. A imaginação, faculdade benfazeja, triunfa sobre a distância que nos separa, representando vocês, constantemente do meu lado, por toda parte a que dirijo meus passos." (F LORESTA: 1982; 59)

Além das reflexões sobre sua condição de viajante e dos devaneios que a fazem lembrar dos parentes, esta narradora-personagem recua ainda mais para dentro de si através da memória, para procurar reminiscências da infância ou para ir ao encontro de familiares distantes, estejam eles vivos ou não, até como forma de novamente reviver um momento de felicidade. Está configurada assim, mais uma viagem: a que conduz ao passado íntimo da personagem. Talvez seja esta a mais importante, se se considerar que é a que mais nostalgia provoca e a que permitirá à personagem elaborar analiticamente suas perdas e a própria solidão.

“Quase me esquecia de tratar com vocês da impressão que, antes de deixar Stuttgart, produziu em mim a visão dos lagos que se acham nas proximidades da cidade. Os de meu país natal fizeram-se presentes a meu espírito com toda a poesia dos anos de minha infância." (FLORESTA: 1982; 96)

A narradora desfaz, pois, ao longo do trajeto de sua viagem-escritura, a linearidade temporal, fundindo muitas vezes o passado, o presente e o futuro cronológicos. Seu compromisso com o mundo real e o espacial é relativo, pois manipula-os subjetivamente, e cada momento do presente parece conter os momentos anteriores. A simultaneidade de planos que caracteriza a escrita moderna, encontra-se, de certa forma, já neste Itinerário de uma viagem à Alemanha, as- 
sim como quase a reprodução do fluxo da consciência e quase um monólogo interior. Se o narrador não desaparece do texto, por outro lado se identifica com o EU autobiográfico que, afinal, é quem comanda a cena textual.

Neste Itinerário, como aliás em quase todos os livros de Nísia Floresta, a narradora confunde-se com a autora, e em nenhum momento esconde a condição biográfica de sua escritura. Ao contrário, insiste em revelá-la com informações precisas de sua vida, como o nome dos filhos e irmãos, as datas de morte da mãe e do esposo, e inúmeras outras referências passíveis de serem checadas. Ela termina por estabelecer com o leitor o "pacto autobiográfico", quando revela a identidade comum entre a autora das cartas (do livro) e a personagem principal, a narradora, que conta a experiência de viajante. Nem mesmo é necessária a menção de seu nome ao longo da narrativa, pois ele já é evidente e está escrito na capa do livro. (LEJ EUNE : 1975; 33)

Nísia Floresta parece ter vivido bem de acordo com sua época: dramatizou os próprios conflitos, e levou os sentimentos e as emoções ao extremo de sua potencialidade. É o modelo romântico de comportamento, tão conhecido não só em personagens de romances como na vida de tantos escritores. E a autora-personagem vive conforme o modelo ficcional: se o presente não é satisfatório, refugia-se nas próprias lembranças e idealiza o passado, seja ele o da História, seja ele o seu, pessoal. Faz mais: constrói ainda sua narrativa segundo este mesmo modelo romântico.

Examinemos agora o outro livro de viagem - Trois ans en Italie, suivis d'un voyage en Grèce.

O séjour italiano de Nísia Floresta inicia-se em 19 de março de 1858 e termina em meados de 1861, tempo mais que suficiente para percorrer o território da Península mais de uma vez e conhecer também a Sicília e a Grécia. Permite-nos supor também que, assim como alguns locais foram visitados mais de uma vez, a narrativa pode ter sido revista, apesar das reiteradas negativas da autora sobre modificações do texto. Em todo caso, dada a demora de sua publicação, foram necessárias algumas anotações de pé-de-página atualizando informações, como quando a autora descreve o "desagradável trajeto de sete horas, por uma estrada árida e deserta" a caminho de R oma e depois informa que, "no momento em que publicamos estas páginas uma estrada de ferro transporta passageiros, em duas horas, de Civita-Vechia a R oma". O segundo volume, onde aparece o maior número destas observações, traz uma advertência aos leitores: informa que o livro havia sido escrito antes dos "grandes acontecimentos" (a luta pela independência) que então estavam sendo contados. (FLORESTA: 1872; 47)

A preocupação em esclarecer a relação cronológica entre o tempo da escritura e o dos fatos contados revela-nos a consciência autoral sobre a importância 
dos tempos em questão e também sobre o procedimento usado ao antecipar, algumas vezes, dados da história, anunciando as conseqüências de uma ou outra situação.

Naturalmente, antes de Nísia, muitos tinham sido os escritores que visitaram o solo italiano e que fizeram apaixonados relatos de sua estada. E ntre os mais ilustres, lembramos Chaucer, que por duas vezes cruzou este território no século XIV para conhecer Petrarca e a R enascença Italiana, e M ontaigne que descreveu tudo com pormenores em J ournal de voyage en I talie. A segunda metade do século XVIII, considerada a "idade de ouro da viagem à Itália", registrou um sem número de relatos, como o do astrônomo francês $L$ alande, que publicou um livro de enorme repercussão: Voyage d'un françois en I talie (1769); o abade Coyer, autor de Voyages d'I talie et de Hollande (1775); e G oethe, que perambulou durante dois anos, de 1786 a 1788, e depois escreveu Italienische Rei se, composto de cartas dirigidas a Charlotte von Stein. Este livro é importante principalmente por conter a "educação do olhar" goetheano que tal viagem propiciou, e alguns princípios da "arte de viajar", preconizados anteriormente por Rousseau.

Henri B eyle também residiu na I tália pelo menos durante sete anos - de 1814 a 1821 - e a primeira obra que assinou com o pseudônimo que o tornaria famoso, Stendhal, foi justamente Rome, Naples et Florence (1817), não menos citada que sua conhecida Promenades dans Rome (1829). E Lord B yron, seduzido pelos ares italianos, escolheu a I tália como segunda pátria em 1816 na época em que escrevia o Don Juan.

Entre os franceses, Victor Hugo morou na Itália alguns anos quando criança; e, Chateaubriand, como adido na E mbaixada de R oma, também conheceu de perto este país e escreveu Lettre sur la campagne romaine e Voyage en Italie. George Sand fez sua viagem acompanhada de Alfred de M usset e brindou os leitores com Lettres d'un voyageur. Musset também recolheu contos populares e os reuniu em Contes d'Espagne et d'I talie (1830). Michelet esteve em 1830 em terras italianas e publicou no ano seguinte Histoi re romanine; e L amartine, secretário nas E mbaixadas de Nápoles e de F lorença, escreveu Harmonies e Le voyage en Orient (1835), acerca de sua viagem aos lugares santos do cristianismo. Mérimée circulou pela Inglaterra, E spanha, G récia e a I tália nesta época, e seus livros, Colomba e Carmen, revelam bem as influências que tais excursões deixaram em seu espírito.

Assim, após estes e tantos outros viajantes, era chegada a vez de Nísia Floresta conhecer a Itália. Ela não realiza sua viagem incógnita, como Goethe, nem percorre o país em algumas semanas, como alguns fizeram e ela mesma fez em sua excursão à A lemanha. A o contrário, demora-se por três longos anos - tempo mais que suficiente para conhecer e rever os lugares que Ihe interessavam, fazer amizades e residir ora em R oma, ora em Veneza, Florença ou Milão. 
Em Trois ans en Italie, Nísia Floresta inicia como um diário de viagem e termina o segundo volume como uma crônica histórica. Opera ainda neste texto uma singular fusão entre as duas formas de diário, "o de viagem" e o "diário íntimo", além de guardar uma semelhança com o gênero epistolar, quando se dirige a outra pessoa. M esmo no diário, aqui e ali surge um vocativo que se refere à pessoa com quem a narradora dialoga (ou "monologa"), que tanto pode ser alguém de seu relacionamento, como um personagem histórico, uma cidade, um país, um cidadão qualquer.

Esta oscilação entre diário íntimo, diário de viagem e mesmo carta vem caracterizar a narrativa desta escritora que parece não tratar um tema objetivamente, sem se colocar no centro da questão. Em praticamente toda sua obra, os sentimentos e pensamentos mais íntimos são divulgados, pois ela não hesita em registrar dados autobiográficos e revelar seus pontos de vista em letra impressa. Esta subjetividade poderosa também vai estar presente neste texto, pontuando-o com reflexões, opiniões e, principalmente, referências à sua vida particular.

Como a maioria dos escritores de narrativas de viagens, que buscavam conhecer o que os viajantes anteriores tinham dito, Nísia F loresta ao registrar suas impressões da estada em terras italianas, também vai mencionar os livros dos que a precederam. Afinal, referir-se a eles representava uma amostra de erudição e uma atitude de reverência para com estes textos.

“Onde tantos grandes gênios, tais como Goethe, Byron, C. Delavigne e Lamartine vieram entreter-se com a sombra lastimosa do sublime cantor da J erusalém Libertada! A minha pobre pena nada poderia acrescentar. Mas uma lágrima sinceramente derramada nunca é demais para uma desgraça e essa lágrima foi, sem dúvida, a primeira derramada por uma mulher brasileira na prisão de Tasso." (FLORESTA: 1864; 227, grifos meus)

Em Veneza, lembra-se de Byron e cita-o várias vezes a partir mesmo de uma estrofe sua que utiliza como epígrafe: "Oh Venice! Venice! When thy marble walls..." A pós reverenciar o mestre, ela se introduz com sutileza na ampla malha de textos sobre a Itália, utilizando-se de uma falsa modéstia para abrir e garantir seu espaço:

“A pós as tocantes e admiráveis páginas que o poderoso gênio de Lord Byron consagrou a esta bela R ainha do Adriático, decaída de sua glória passada, não se deveria jamais ousar dizer algo sobre ela, pois tudo fica abaixo da descrição viva, animada, entusiasta e sublime, saída daquela pena inflamada, cuja beleza poética não tem rivais em nossos dias. M as, assim como os tênues raios passam através da plena claridade do sol e os modestos riachos correm ao lado dos grandes rios, dessa mesma maneira irei respingando, aqui e ali, algumas flores murchas de meu pobre espírito, para fazer uma humilde guirlanda que levará 
à minha querida pátria uma recordação de minha estada junto ao bom povo italiano." (FLO RESTA: 1864; 237)

Assim, em Trois ans en I tali e ela intertextualiza o próprio relato com os mais conhecidos, principalmente os de Byron e G oethe, citando-os e comentando os pontos comuns entre seu comportamento e o deles. Não deixa também de mencionar a existência de outros textos de viajantes, dos quais discorda, que emitiam opiniões apressadas ou alteravam significativamente a realidade do país. E apesar do numeroso repertório que encontra, ainda assim ela inovará o gênero, principalmente na abordagem sensível que faz do tempo presente italiano. O passado é importante sim, mas enquanto referência para se compreender e valorizar o momento presente. Da mesma forma ela age com relação à Grécia: apesar de as fantásticas ruínas estarem diante de seus olhos, não deixa de observar como os jovens se comportavam e de se inteirar da situação política, social e cultural do país.

Não é, portanto, apenas uma turista que aí está, mas uma mulher portadora de uma consciência política forjada num passado de lutas contra o preconceito e as injustiças sociais. Nísia F loresta, é bom lembrar, desde a infância conviveu com fases revolucionárias em que se defendiam propostas liberais (em 1817 e 1824, em Pernambuco; de 1835 a 1838, com a Farroupilha, em Porto Alegre; e em 1848, com a R evolução Praieira, também em Pernambuco), responsáveis, aliás, pelas inúmeras mudanças de domicílio ao longo de sua vida. O fato de ela já conhecer $G$ aribaldi desde a época em que residia no sul do Brasil, por ocasião da Farroupilha, torna mais elucidativo seu entusiasmo pelo revolucionário italiano, quando ele toma a frente dos combates. (DUARTE : 1995)

Por todas essas razões, o relato nisiano tinha que ser diferente. As sucessivas derrotas liberais que presenciou marcaram seu olhar com uma outra sensibilidade, permitind o que ela visse tais momentos singulares, de forma bem diversa da que foi vista pelos europeus. A autora tinha o olhar atento para a história da opressão, cujas ruínas à sua volta eram apenas um referente. A simbiose entre o autobiográfico, a reflexão historiográfica e a narrativa de viagem contribuirá para tornar o seu relato um texto ímpar, diverso dos conhecidos até então.

Também em Trois ans en I talie podem ser observados alguns níveis narrativos. O primeiro conteria a viagem propriamente dita, com as informações acerca de cada cidade, os contratempos, os passeios, as festas populares, as novas amizades, os salões, os assuntos discutidos, enfim, o conjunto de pormenores que preenchem cada instante presente de uma viagem. O segundo traria a incursão que realiza em seu interior, seja em busca de lembranças de um passado familiar, seja nos instantes em que se isola do presente exterior próximo e se refugia em 
experiências de caráter íntimo. E em um último nível, o terceiro, teríamos a sua imersão pela História, com reflexões e tomadas de posição acerca dos acontecimentos político-sociais. A narradora revela-se uma sutil observadora e analista de comportamentos, ao perceber os prenúncios da revolução que se aproximava, neste momento-limite em que se encontrava o povo italiano. Trois ans en I talie é precisamente o livro em que melhor se delineia a ideologia política da autora, tanto por ter sido realizado num momento de maturidade intelectual, como por refletir as transformações sociais e políticas italianas. Nísia F loresta, como croni sta da história italiana, expõe seus pensamentos liberais, toma partido e defende com paixão seu ponto de vista.

Mas, por vezes o relato de viagem transforma-se em diário íntimo. Neste momento, a autora registra os pensamentos de caráter pessoal, os devaneios, a confissão de saudades dos parentes e da pátria ou a alegria pela chegada de notícias. Trata-se, portanto, do espaço narrativo onde encontramos informações nitidamente autobiográficas, como as lembranças de aniversários e morte dos entes queridos. Segundo a autora, os desabafos e confidências só encontrariam eco entre aqueles que, como ela própria, viajavam e estavam distantes da pátria e dos seres queridos, pois:

"Somente para essas pessoas têm sentido as poucas linhas que acabam de escapar deste coração, hieróglifo indecifrável para o vulgo, que talvez me lerá indiferente a essas coisas emanadas do coração e que buscará nessas páginas somente a narrativa das coisas, tão repetidas por outros viajantes, com talento e um gosto formal refinado, que não pretendo exibir de maneira alguma." (FLORESTA: 1864; 104)

Em todo caso, os momentos autobiográficos são aqui bem menos numerosos do que os que aparecem no livro anterior, que relata a viagem à Alemanha e abriga lembranças de toda ordem. E m 10 de abril, por exemplo, ela recorda o dia em que partiu do Brasil para a Europa pela segunda vez. R efaz mentalmente as circunstâncias da partida, as despedidas no porto do R io de J aneiro, pelo simples prazer de se lembrar do passado e referendar alguns momentos de sua vida:

“...retomei o vôo para o velho mundo, onde procuro, em vão, através das viagens, adormentar a tristeza d'alma. E quanto mais se sucedem os dias, os meses e os anos, mais sinto o vazio que se faz em torno de mim." (FLORESTA: 1864; 40)

Aqui e ali a persona da viajante-solitária aparece. Agora, tal uma ave de arribação, ela alçou vôo, distanciou-se do ninho e em vão procura sossego e paz de espírito em outras plagas. Ao fazer de si e de sua vida personagens do texto, a 
narradora arrisca-se muitas vezes a passar uma imagem contraditória, tal a recorrência de algumas das suas personae e o modo pelo qual elas se apresentam em relação aos demais dados contidos na narrativa. Assim, ao mesmo tempo que cultiva a auto-imagem de escritora-viajante e de "mulher forte", que resiste às intempéries da vida e às fadigas dos passeios, cultiva também as imagens da mãe extremosa e dedicada, da viúva fiel que renunciou à felicidade e da brasileira saudosa da terra natal.

A persona que predominou no Itinérári o de uma viagem à Alemanha - a da mulher romântica, melancólica e solitária - parece surgir neste livro quase como uma imposição estética, pois não deixa de ser contraditória a confissão de tristeza à noite quando escreve no diário e o entusiasmo pelas belezas artísticas que viu durante o dia. A imagem que se impõe sobre as demais, em Trois ans en I talie, é, acima de todas, a da mulher intelectual e amadurecida, autora de livros conhecidos, que ocupava seu tempo estudando os novos países, escrevendo, ou freqüentando os mais diversos cursos. Esta imagem de mulher pública fica ainda mais evidente quando nos deparamos, ao final do livro, com a transcrição da "carta de despedida" a F lorença, que publicou nos jornais da cidade em 10 de julho de 1861, dia de sua partida, dando conta do seu carinho pelo país e pelas pessoas que conheceu. Como seu séjour nestas terras não se passou de maneira discreta, nem limitado ao âmbito privado de alguns poucos relacionamentos, de certa forma, justifica-se sua despedida pública. (DUARTE : 1995)

Se em I tinerário de uma viagem à Alemanha, a autora tentou recompor as próprias "ruínas" interiores, despedaçadas no sentimento de perda que então a dominava, dois anos depois, em Trois ans en Italie ela parece buscar a superação do individualismo em prol do social e do coletivo. Natural, pois, que neste livro manifeste preocupação com os destinos dos povos. As "ruínas morais" que percebe, estão expressas principalmente nos sistemas de governo autoritários, na exploração do trabalho escravo, na dominação tirânica de um país sobre outro, no abuso da força física e em todos os tipos de tortura que se pratica sobre os vencidos. "Quando os bárbaros desaparecerão da terra?", é a pergunta que faz, instigand o o leitor à reflexão.

A esperança em tempos melhores é outro elemento que pontua esta narrativa. No alto do Vesúvio, ela vê além da paisagem: naquele instante "reapareceu a esperança radiosa em uma nova era, que marcará a regeneração dos povos entorpecidos sob o peso das facções". Seu olhar parecia enxergar sempre mais à frente, à frente mesmo da maioria dos pensadores contemporâneos, refletindo a necessidade íntima de se refugiar num outro ideal. Como o presente não correspondia aos seus anseios, ela busca o futuro, não mais o passado, em atitude que, ao final, não deixa de ser também uma solução romântica. 
“Ó futuro, futuro! quanta doce consolação não se experimenta ao pensar na melhoria e na felicidade que reservas a esta pobre Humanidade, já sujeita a tantos flagelos naturais e inevitáveis, arrastando ainda o pesado grilhão da escravidão física e moral, com o deplorável cortejo de desgraças!" (FLORESTA: 1864; 147)

Voltar-se para o futuro equivalia, segundo a lógica do espírito romântico, a projetar para depois o desejo de justiça e de paz que não era possível no seu tempo. Havia entre os românticos uma preocupação de cunho libertário que ultrapassava a questão regional e até a nacional, pois queriam abarcar a defesa de todos os oprimidos, de todas as raças. Esta herança utópica da ideologia progressista, cuja visão era universal, data dos fins do século XVIII e do início do XIX.

"Possam os governos de todos os países civilizados escutar os gritos da agonia prolongada desses desgraçados oprimidos, brancos e negros! E que a libertação geral dos escravos no Novo Mundo como no Velho Mundo, assinalando uma das mais gloriosas épocas nos anais da Humanidade, evidencie a elevação das idéias do século dos maravilhosos progressos intelectuais." (FLORESTA: 1864; 158)

A autora está em M essine, na Sicília, quando surgem nos jornais as notícias da deflagração do movimento revolucionário pela unificação italiana. Seu texto, a partir de então, reforça uma feição de crônica-histórica, por conter não só transcrições de matérias jornalísticas relativas aos avanços e às vitórias dos liberais, como também cartas de Garibaldi à população e comentários da autora com "os votos mais ardentes" pelo triunfo completo da revolução. A cronista toma partido e não esconde em nenhum momento o quanto estava envolvida pelos acontecimentos. O Monitore Toscano, II Movimento, Consti tutionnel e La Nazi one são alguns dos jornais de onde extraiu notícias, contribuindo para atestar a veracidade dos fatos históricos que serviram de base ao seu texto. E m maio de 1860, por exemplo, La Nazione publicou um apelo às mulheres italianas, para que elas demonstrassem seu "amor à causa" doando seus adereços, supérfluos em tempo de guerra, para a compra de armas, assinado por G aribaldi, que Nísia F loresta fez questão de incluir em suas anotações. O tom panfletário da matéria jornalística parece contaminar o texto nisiano que, mais do que nunca, mostra-se partidário, defendendo suas idéias com entusiasmo.

Por tudo isso, este "diário de viagem" se constitui num valioso documento para o estudo da História italiana, principalmente porque contém em suas páginas a história observada pela perspectiva dos dominados. Trois ans en I talie, envolvido por um discurso de caráter histórico, guarda análises sensíveis e eruditas acerca do passado, do presente, da vida social e política, dos costumes do povo, 
das tradições, enfim, de tudo que mais caracterizava a vida na I tália naqueles idos de 1860, além das citações de autores e obras e da multiplicidade de nomes de personalidades. O livro termina por compor um painel social-político, tornandose uma importante fonte de pesquisa para estudos de natureza científica, referentes, por exemplo, à história, antropologia, sociologia, política, história da literatura e das artes.

As referências à experiência pessoal ou ao caráter autobiográfico presente nos Trois ans não chegam a comprometer de forma decisiva o testemunho de época que o livro possui, pois não impediram o registro da crônica política, da crítica cultural e das reflexões sobre a história daquele país. Ao contrário, enriquece este mesmo testemunho na medida em que apresenta as reflexões e conclusões de uma viajante erudita, que conhece e admira o passado de lutas do povo italiano.

É nesse aspecto que reside a maior das diferenças entre este livro e o anterior. O autobiografismo aqui não se manifesta de forma individualista como no I ti nerário. É a autora que narra, mas ela ultrapassa as limitações de um diário, para se revelar uma cronista que faz a documentação das experiências históricas de um povo. A autora se inclui deliberadamente na trama do mundo e passa a fazer mesmo parte do espetáculo ao emitir opiniões, tomar partido ou vibrar com a vitória dos revoltosos.

Enfim, esta é Nísia F loresta. U ma mulher brasileira de ol har viajante e reflexivo, sujeito periférico dotado de perspicácia e ousadia, a dialogar de igual para igual com o discurso das metrópoles. E m sua trajetória de vida ela nada mais faz que ampliar os passos da jovem nordestina, autora de Direitos das mulheres e injustiça dos homens, que já anunciava, em 1832, uma postura altiva perante o olhar estrangeiro.

\section{Referências bibliográficas}

CHERBULIEZ, J oel. Revue critique des livres nouveaus. Seconde sèrie, $1^{\text {re }}$ année. Paris: Chez J oel Cherbuliez Librairie, 1858, p. 23.

DUARTE, Constância Lima. Nísia Floresta: vida e obra. Natal: E ditora da UFR N, 1995.

FLORESTA, Nísia. I tinerário de uma viagem à Alemanha. Trad. Francisco das Chagas Pereira. Natal: Editora Universitária, 1982.

FLORESTA, Nísia. Trois ans en I talie, suivis d'un voyage en Grèce. I - Paris: E. Dentu, 1864.

FLORESTA, Nísia. Trois ans en Italie, suivis d'un voyage en Grèce. II - Paris: E. Dentu, 1872.

FLORESTA, Nísia. Itinerário de uma viagem à Alemanha. Trad. Francisco das Chagas Pereira. Apresentação e notas biográficas Constância L. Duarte. Florianópolis: Editora Mulheres, 1988. 
FLORESTA, Nísia. Três anos na Itália. Trad. Francisco das Chagas Pereira. A presentação Constância L. Duarte. Natal: E ditora da UFR N, 1999.

GARRETT, Almeida. Viagens na minha terra. Seleção, notas e glossário de Ofélia M alheiro Caldas. 2 v. Coimbra: Atlântida, 1961.

HUGO, Victor. Voyages. Avec une notice biographique, des notes, des notices littéraires et des notes explicatives par Philippe van Tieghem. Paris: Librairie Hachette, 1941.

LEJ EUNE, Philippe. Le pacte autobi ographique. Paris: Seuil, 1975.

MICHÉA, René. Le voyage en I talie de Goethe. Aubier: É ditions M ontaigne, 1945.

ROUSSEAU. J ean-J. E mílio ou Da educação. Trad. Sérgio Milliet. São Paulo: Difusão E uropéia do Livro, 1968. 